
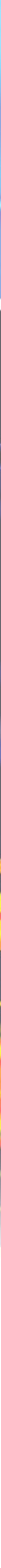

Підвищує розумову і фізичну працездатність.

У складі комплексної терапії:

когнітивні порушення при органічних ураженнях головного мозку (у тому числі наслідки нейроінфекції). 


\title{
«Постковідний синдром»: неврологічні прояви та лікування українським препаратом Когнум
}

\author{
О.В. Новікова \\ Національний університет охорони здоров'я України імені П.Л. Шупика, Київ, Україна
}

Анотація. У статті розглянуті особливості вірусних уражень під час пандемії COVID-19 та патогенетичне обґрунтування призначення препарату Когнум у лікуванні неврологічних ускладнень після перенесеного захворювання.

Ключові слова: COVID-19, неврологічні ускладнення, Когнум.

\section{Вступ}

Наразі людство зустрілося з викликом, який вразив нашу планету, - пандемією COVID-19, яка охарактеризувалася масштабним негативним впливом на соматичне та психічне здоров'я людей, економіку та ще цілим ланцюгом непередбачених обставин у майбутньому. Світ «закрився»: страх, розгубленість, розпач лікарів та пацієнтів панували на першому етапі медичної допомоги в усіх, навіть розвинених, країнах. Про це свідчать численні виступи та інтерв'ю вчених: імунологів, вірусологів, епідеміологів, лікарів майже усіх клінічних спеціальностей на міжнародних онлайн-конференціях. Ціною неймовірних зусиль, залучаючи весь свій досвід, українські клініцисти на чолі з професором О.А. Голубовською разом із зарубіжними колегами розробили поетапні клінічні протоколи (в тому числі персоніфіковані підходи), що досить суттєво допомогло лікарям впевнено та результативно боротися з різними проявами хвороби, а у пацієнтів зменшився панічний страх при появі симптомів захворювання [1].

Далеко не всі реконвалесценти з негативним тестом/тестами на SARS-CoV-2 повністю відчувають себе здоровими. Після перенесеної коронавірусної хвороби зростає кількість осіб, які відчувають гнітючий вплив залишкових наслідків після, як здавалося, вже перенесеного гострого процесу і виснажливого лікування. Незабаром після виписки або через 1-2, а іноді через декілька місяців, зненацька виникають та зберігаються різноманітні скарги та симптоми, що декомпенсують пацієнтів і змушують звертатися за допомогою до лікаря, зокрема невролога. Страх перед ускладненнями хвороби, вимушена соціальна ізоляція й невпевненість у майбутньому роблять свій внесок, спричиняючи тривожні та стресові розлади. Крім психосоціального стресу, пов'язаного з пандемією, науковці вивчають прямі ефекти вірусу SARS-CoV-2 на центральну нервову систему (ЦНС).

Про особливості вірусу, що викликав всесвітню пандемію, докладно розповідав провідний вірусолог, імунолог академік В.П. Широбоков [2]. У структурі будови SARS-CoV-2 існує 4 вірусних білки. Ще декілька закодованих вірусом білків знаходиться в цитоплазмі інфікованої клітини. Важливим $\epsilon$ те, що S-білок «шипа» вірусу, маючи тривимірну структуру, утворює специфічне рецепторне поле з дуже високою тропністю до трансмембранного клітинного рецептора - білка ангіотензинперетворювального ферменту (АПФ)-2. Таким чином коронавірус проникає у клітину, а тропність до АПФ забезпечує йому контакт з органами-мішенями. АПФ займає близько $25 \%$ структури клітинної мембрани епітеліальних клітин, і перш за все альвеолярних. Доведено, що з віком наявність та концентрація цього білка підвищуються, тобто мінімальна у дитячому віці і максимальна в осіб віком $>60$ років. Найбільша їх кількість в альвеолярному апараті легень та дещо менша - у кишечнику.

Найвразливіша ланка у патогенезі ураження — легенева система та їі альвеоли, де розгортається псевдонабряк легень з проявом гострого респіраторного дистрес-синдрому. Цим, найвіро- гідніше, пояснюється здебільшого легкий перебіг захворювання у дітей та осіб молодого віку, на відміну від пацієнтів більш похилого віку. Такі особливості простежуються і в клінічній картині перебігу хвороби. У гострий період при тяжких та середньотяжких проявах у них найчастіше відмічають бронхолегеневий синдром із вираженою гіпоксією та дисфункцією кишечнику [2].

Відомо, що всі віруси, окрім того, що $\epsilon$ патогенними, токсигенними, $є$ ще й вазотропними, тобто на фоні вірусних захворювань підвищується проникність судин (їх порозність) та змінюються реологічні властивості крові. При COVID-19 простежується очевидна картина їх нейротропності. Ймовірною версією нейротропності саме цього вірусу, на думку вчених, $\epsilon$ те, що він використовує спайковий білок для прикріплення віріону до клітинної мембрани в стовбурі, в таламусі та його безпосередню взаємодію з рецептором АПФ-2. Ще один шлях, що може використовувати вірус для проникнення у ЦНС, - висхідний, через решітчастий лабіринт по волокнах нюхового нерва, далі y trigonum olfactorium, досягаючи структур головного мозку. Такий патогномонічний синдром, як аносмія, $\epsilon$ підтвердженням цього шляху проникнення SARS-CoV-2 у нейронний апарат ЦНС.

За сучасними даними, існує вагома інформація про трансендотеліальний шлях проникнення вірусу, що супроводжується вираженою системною запальною реакцією, яка лежить в основі вже вторинного ураження (запального процесу) нервової системи і призводить до дезорганізації мікроциркуляторного русла 3 наступним ураженням паренхіматозних органів і розвитком ураження структур головного мозку. Ендотеліальній дисфункції належить основне місце в дезорганізації мікроциркуляції в цілому, однак для паренхіматозних органів вона відіграє особливу роль [3]. При цьому відмічаються переважно реакція вазоконстрикції, уповільнення кровообігу та перфузійний дефіцит з гострою ішемією органів, у відповідь на яку посилюються реакція запалення, набряк, набухання тканин та гіперкоагуляція. Формується так званий ендотеліїт, спровокований COVID-19. У більшості пацієнтів з тяжким та найтяжчим перебігом хвороби на тлі ураження дихальної системи часто виявляють синдром поліорганної недостатності з розвитком коагулопатії - синдромом дисемінованого внутрішньосудинного згортання. Про це можуть свідчити рівень D-димеру, фібриногену, протромбінового часу та кількості тромбоцитів. Зміна цих параметрів у бік погіршення може бути вагомою підставою для екстреного призначення більш дієвих низькомолекулярних гепаринів або заміни дози на більш високу (під контролем вищезазначених показників).

\section{6'єкт і методи дослідження}

Під нашим спостереженням знаходилися 45 пацієнтів віком 15-82 роки (19 жінок та 26 чоловіків), які перенесли COVID-19 різного ступеня тяжкості з різними основними клінічними проявами. Діагноз COVID-19 підтверджено клінічно і лабораторно в усіх хворих. При цьому у 9 пацієнтів, в яких клінічна картина не викликала сумнівів, тест полімеразно-ланцюгової реакції 
був негативним, діагноз підтверджено на підставі наявності антитіл до SARS-CoV-2 тільки наприкінці гострого періоду, на 21-27-й день хвороби.

В усіх пацієнтів дебют захворювання розпочинався з вираженого загальноінфекційного та інтоксикаційного синдрому, що тривав частіше 3-7 днів та супроводжувався назофарингітом без аносмії - у 2, назофарингітом, агевзією та аносмією - у 5, назофарингітом та аносмією - у 6, гострим гастроентероколітом - у 2, пневмонією та аносмією - у 3, пневмонією - у 22 та пневмонією, яка ускладнилася гострим порушенням мозкового кровообігу (ГПМК), - у 5 пацієнтів. У двох із останніх ГПМК розвинулося під час лікування пневмонії у відділенні реанімації, у одного через 1 тиж, ще у одного - через 4 міс після перенесеної пневмонії. У однієї пацієнтки, що перенесла COVID-19 з аносмією та агевзією, майже через 1 рік розвинулося ГПМК у вертебробазилярному судинному басейні з вогнищем ішемії у мосту (аносмія та агевзія у неї зберігалися увесь цей період - майже 1 рік). Всі ці пацієнти мали в анамнезі гіпертонічну хворобу, їх вік - 2957 років. ГПМК, за даними магнітно-резонансної томографії головного мозку, розцінювали як ішемічний інсульт, у 3 та з геморагічним паренхіматозним просякненням - у 2 пацієнтів. Однак практично на усіх знімках вогнища ураження не відповідали певному судинному басейну, тобто ураження були двобічними, іноді поширювалися на підкіркову зону, мозочок, стовбур головного мозку. У двох пацієнток через 2 міс після пневмонії з'явився екстрапірамідний синдром, переважно тремтлива форма. Детальний аналіз клініко-неврологічного статусу у динаміці та даних магнітно-резонансної томографії головного мозку свідчить про те, що у 3 пацієнтів ураження головного мозку більшою мірою відповідало енцефалітичному, а не судинному процесу [4]. Відповідно імунологічні та вірусологічні дослідження (ліквора та крові) у зіставленні з нейровізуалізацією та симптоматикою, можливо, дадуть відповідь на ці запитання.

\section{Результати та їх обговорення}

Основні скарги, з якими пацієнти зверталися до невролога після перенесеного COVID-19, - виражена («неймовірна») слабкість, що була буквально «неподоланною» у перші тижні після хвороби. Крім цього, відзначали підвищену емоційну виснажливість, зниження працездатності, біль у кістках та суглобах, прискорене серцебиття, запаморочення, безсоння, неповноцінний сон, неможливість сконцентруватися, цефалгію, безпідставну неконтрольовану дратівливість, байдужість, погіршення пам'яті. Вважаємо за необхідне наголосити на тому, що скарга на виражену слабкість, виснажливість була часто пріоритетною як у хворих, що перенесли хворобу у легкій формі та середньої тяжкості, так і після тяжкої пневмонії (в тому числі у хворих молодого віку). Саме слабкість, неможливість виконувати мінімальні, звичні навантаження, а також погіршення пам'яті примусили пацієнтів звернутися вперше в житті до невролога.

В тих, хто переніс ГПМК, були виражені рухові, чутливі розлади, в одному випадку мав місце бульбарно-псевдобульбарний синдром, ще в одному - геміанопсія, тобто очевидно, що пріоритетними були інші скарги.

Характерним феноменом при вірусних захворюваннях $\epsilon$ порушення кровообігу головного мозку на рівні мікроциркуляції, що пов'язане з ураженням артеріол і капілярів, а також порушення реологічних властивостей крові [5]. Слід зазначити, що при такому захворюванні, як COVID-19, ураження судин, які забезпечують кровообіг ЦНС, і дистрофічно-деструктивні зміни у нейронах «накладаються» на токсигенний та гіпоксичний чинники.

Найважливішу роль у патогенезі тут можуть відігравати нейрометаболічні порушення і хронічна ішемічна гіпоксія, що в результаті призводить до порушень енергетичного потенціалу нейронів, зниження біосинтезу макроергічних з'єднань, зрушень у структурно-функціональному стані нейрональних мембран і розвитку оксидативного стресу, а в результаті - до дистрофії і дегенерації нейронів, порушень нейромедіаторного балансу і прогресуючих змін з боку неврологічної і психічної функцій.
У цій роботі аналізувати випадки, які мали місце переважно на амбулаторному неврологічному прийомі та у стаціонарах м. Київ. Тому детальне вивчення когнітивних розладів з аналізом нейропсихологічних тестів не було метою цієї публікації.

3 урахуванням особливостей етіопатогенезу хвороби, поліморфності скарг пацієнтів та об'єктивних клініко-неврологічних симптомів, які мали місце під час наших спостережень, цілком зрозумілим $\epsilon$ те, що монотерапія одним лікарським препаратом неможлива. Тому у комплексному лікуванні таких пацієнтів враховували всі можливі особливості і ризики. Водночас, зважаючи на те, що такі скарги, як виснажливість, виражена слабкість, запаморочення, погіршення концентрації уваги, пам'яті, були притаманні 90\% пацієнтів, нашою метою було призначити препарат, який поєднав би у собі бімодальні властивості, анксіолітичні та ноотропні.

Таким ГАМК-ергічним препаратом із своєрідним механізмом дії $\epsilon$ гопантенова кислота (ГПК), або кальцію гопантенат. За своєю хімічною структурою ГПК являє собою кальцієву сіль $\mathrm{D}(+)$-пантоїл-гама-аміномасляної кислоти i $\epsilon$ гомологом $\mathrm{D}(+)$ пантотенової кислоти (вітаміну В B $_{5}$, в якій бета-аланін заміщений на ГАМК [6]. ГПК $\epsilon$ природним метаболітом ГАМК у нервовій тканині, на відміну від інших ГАМК-похідних ноотропних препаратів. Саме ця особливість дозволяє розраховувати, з одного боку, на максимальну ефективність цього засобу, що впливає безпосередньо на фізіологічні механізми регуляції когнітивної та психоемоційної сфери і судинні реакції. 3 іншого боку, ця особлива властивість дозволяє забезпечити максимальну безпеку препаратів ГПК на відміну ноотропів-ксенобіотиків [7]. При проникненні через гематоенцефалічний бар'єр ГПК максимально концентрується насамперед у ключових регіонах головного мозку - у корі та гіпокампі, забезпечуючи оптимізацію когнітивних процесів, на відміну від інших ноотропних препаратів. ГПК чинить активуючий вплив відразу на два провідних «нейромедіатори пам'яті» - ГАМК й ацетилхолін. Однак і цим не вичерпуються когнітивні механізми дії ГПК. За рахунок певної спорідненості з дофаміновими $\mathrm{D}_{2}$-рецепторами, які беруть участь в активації пізнавальних процесів та засвоєння, психічній працездатності і т.д., досягається залучення в ефекти ГПК третього «нейромедіатора пам'яті» - дофаміну. Саме $\mathrm{D}_{2}$-агоністи сьогодні розглядають як новий перспективний напрямок ноотропної фармакотерапії. При цьому інші ГАМК-ергічні ноотропи не здатні будь-яким чином впливати на дофамінові рецептори. Однак окрім системних нейромедіаторних, ГПК властива і ціла низка цінних з точки зору нейропротекції нейрометаболічних ефектів, що також реалізуються через вплив ГАМК на нейрональному рівні: підвищення енергетичного потенціалу нейронів (накопичення макроергічних фосфатів - АТФ і АДФ, активація тканинного дихання), поліпшення утилізації глюкози, стимуляція білок-синтетичних процесів у нейронах, стабілізація функцій нейрональних мембран. У результаті реалізації цих ефектів підвищується стійкість нейронів до ішемії, гіпоксії та/або дії різних токсичних речовин (що розширює сферу застосування ГПК не тільки при дисциркуляторній енцефалопатії, але й інших формах енцефалопатій). Відзначено високу безпеку терапії ГПК. Вищезазначена молекула не утворює активних метаболітів при своїй біотрансформації в організмі людини, тому має мінімальний потенціал під час взаємодії лікарських засобів і тому може безпечно включатися у різні схеми комплексної терапії, що дуже важливо. Крім того, ГПК виявляє здатність до нормалізації обмінних процесів у стінці церебральних судин і антиспастичної дії, тобто до реалізації вазотропних ефектів, також невластивих класичним ГАМКергічним препаратам. Таким чином, навіть короткий перелік основних фармакологічних властивостей ГПК дозволяє зробити висновок про суттєву відмінність цього препарату як від інших «справжніх» ноотропних засобів, так і від препаратів вазотропної, антиоксидантної, нейротрофічної та іншого типу дії за рахунок більш широкого клініко-фармакологічного спектра і, відповідно, можливостей практичного застосування.

Усім хворим призначали препарат Когнум (АТ «Київський вітамінний завод», Україна) у рекомендованих дозах залежно від основного неврологічного синдрому та віку пацієнтів. У біль- 
шості хворих скарги на виражену слабкість, емоційну та інтелектуальну виснажливість, порушення сну, вегетативні розлади регресували через 3-4 тиж лікування. У двох пацієнтів не виявили покращення, але ускладнень з боку внутрішніх органів або інших негативних реакцій не зареєстровано, і вони продовжили лікування.

Особливо слід звернути увагу на ефективність ГПК при цереброваскулярній патології. ГПК успішно застосовують у комплексній терапії не тільки при дисциркуляторній енцефалопатії, але і в реабілітаційний період інсульту та інших захворювань нервової системи, зокрема при гіперкінетичному синдромі різного походження, екстрапірамідній недостатності, порушеннях функції тазових органів (в тому числі при енурезі), у дитячій неврології [8].

Препарат Когнум випускається у формі таблеток, що містять 250 або 500 мг кальцію гопантенату. Разова доза препарату становить 0,5-1 г (2-4 таблетки на прийом), добова - 1,5-3 г. Клінічний ефект ГПК починається не раніше, ніж через 4 тиж від початку лікування, тому рекомендована тривалість прийому препарату Когнум - 1-1,5 міс і більше з повторенням курсу лікування після 3-тижневої перерви. Лікування може бути продовжено до півроку із застосуванням повторних курсів за необхідності.

\section{Висновок}

Таким чином, важливою перевагою препарату Когнум, що вирізняє його від інших ноотропних лікарських засобів, $є$ оптимальне поєднання ефективності, безпеки та можливості застосування при різних неврологічних захворюваннях. У відновний період, зокрема після виснажливих інфекційних захворювань, таких як COVID-19, коли уражені інтелектуально-емоційна сфера, когнітивна функція, турбує виражена слабість, а також при розладах вегетативної нервової системи застосування препарату Когнум значною мірою покращує стан пацієнтів. Про це свідчать і суб'єктивні відгуки, і наші об'єктивні спостереження.

\section{Список використаної літератури/References:}

1. Zupanets I.A., Golubovska O.A., Shkurba A.V. et al. (2020) Prospects for studying the use of quercetin in the treatment of COVID-9. UMJ, 136: 75-78. (In Ukr.).

2. ShirobokovV.P. (2020) Coronavirus and other emergent infections. UMJ, 136:31-33. (In Ukr.)

3. Voznyuk I.A., llyina 0.M., Kolomentsev S.V. (2020) Ischemic stroke as a clinical form and pathogenetic model in the structure of lesions of the central nervous system in COVID-19. Restore Med. Bull. , 4(98): 91-98. (In Rus.)

4. Pilotto A., Masciocchi S., Volonghi I. et al. (2020) The clinical spectrum of encephalitis in COVID-19 disease: the ENCOVID multicentre studi. doi:https://doi.org/10.1101/2020.06.19. 20133991.

5. Andreev V.V., Podunov A.Yu., Lapin D.S. et al. (2020) Clinical and pathogenetic features of cerebral stroke in patients with novel coronavirus infection (COVID-19). Regional blood circulation and microcirculation, 19(3): 46-56. (In Rus.).

6. Boyarchuk 0.D., Vinogradov 0.0. (2013) Biochemistry of stress. Sl «Taras Shevchenko National University», Luhansk, 69 p. (In Ukr.).

7. Burchinsky S.G. (2015) GABAergic agents in the pharmacotherapy of chronic cerebral ischemia. Int. Neurol. J., 1(71): 101-105. (In Rus.).

8. Evtushenko S.K., Sukhonosova 0.Yu., Salnikova V.A. (2015) Experience of using the drug Cognum in children with functional and organic diseases of the nervous system of various etiologies. Int. Neurol. J., 5(75): 41-45. (In Rus.).

\section{«Post-COVID syndrome»: neurological manifestations and treatment with the Ukrainian drug Cognum}

\section{O.V. Novikova}

Shupyk National Healthcare University of Ukraine, Kyiv, Ukraine

Abstract. The article considers the features of viral lesions during the COVID-19 pandemic and the pathogenetic rationale for the use of the drug Cognum in the treatment of neurological complications after the disease.

Key words: COVID-19, neurological complications, Cognum.

Information about the author:

Novikova Olga V. - Candidate of Medical Sciences, Associate Professor of the Department of Neurology № 2 of the Shupyk National Healthcare University of Ukraine, Kyiv, Ukraine.

\section{Address for correspondence:}

Olga Novikova

04112, Kyiv, Dorogozhytska str., 9

E-mail: neurology-education@ukr.net 